\title{
CHIEF PILOTS OF REGIONAL AIRLINES PERCEIVE BASIC INSTRUMENT SKILLS AS MOST IMPORTANT WITH RESPECT TO NEED FOR ADDITIONAL TRAINING OF ENTRY-LEVEL PILOTS
}

William C. Herrick, Ph.D.

Middle Tennessee State University

\begin{abstract}
This study was conducted to identify areas of need for additional flight training of entry-level pilots, as perceived by chief pilots employed by regional airlines. The study used the mail-survey questionnaire method to collect data from 126 randomly selected regional airlines' chief pilots, from a population of 187 ("Regional airline," 1990, Annual). The major finding was that chief pilots perceive the most important training need of entry-level pilots to be basic instrument training (flight or simulator).
\end{abstract}

\section{Introduction}

The hiring practice of the major airlines, acquiring pilots from regional airlines, places inordinate pilot-acquisition burdens on the regional airlines. Hughes (1987) wrote, "The loss of pilots to major carriers has.. . forced those regionals to cancel flights because they lacked pilots to fly the aircraft" (p. 95). Other burdens include; (a) loss of revenues, (b) customer good will, (c) canceled flights, (d) increased training costs, and (e) a series of human-factorrelated airline incidents and crashes (Hughes, 1987; Proctor, 1988; Ott, 1990).

\section{Background and Rationale of the Study}

Chief pilots are considered the top pilots of airlines ("McArtor Challenges," 1987). Further, chief pilots are management personnel, knowledgeable of their airlines' operations specifications, and applicable Federal Aviation Regulations ("Jeppesen," 1981). In addition, many chief pilots are responsible for the hiring of new pilots. For these reasons, chief pilots were selected as the respondents in this study.

A pilot may have the required number of flight-time hours of experience and yet not be proficient in performing all the tasks faced by an entry-level pilot. Ott (1990) wrote, "timed-based training is deficient in that it does not measure the level of learning that has taken place" (p. 68). In addition, it was reported ("Simulators," 1988) that: 
the level of learning that has taken place" (p. 68). In addition, it was reported ("Simulators," 1988) that:

many pilot applicants are unable to pass initial screening tests, primarily because. . . 'Basic instrument skills are not as good as they were five years ago,' a regional airline instructor said, adding that 'we have to be a flight school' and teach basic attitude flying technique instead of 'teaching the aircraft to be flown.' (p. 129)

\section{Purpose of the study}

The purpose of this study was to determine if new-hire entrylevel pilots at regional airlines, certified with the necessary number of flight-time hours, need additional pilot training. And, if additional pilot training is needed, what type of training is required?

\section{Statement of the Problem}

It is possible that, in times of air-carrier-quality pilot shortage, the level and quality of the pilot's flighttraining, before the entry-level hire, is not up to an acceptable standard. At issue is the practice of using flight-time hours of experience rather than the required pilot proficiencies as the main criteria in hiring new pilots (Ott, 1990 , p. 68).

\section{Review of Related Literature}

\section{Introduction}

Schukert and Maples (1990) wrote, "Air transportation in America is in a state of ferment" (p. 1). This contributes to the growing demand for safety-minded, well-trained, proficient, crew-oriented, air-carrier-quality pilots. Therefore, the literature reviewed has been selected to provide a basis for determining entry-level pilot skills at regional airlines.

\section{Entry-Level Pilot Skills}

Entry-level pilot skills are skills that a competent instrument pilot needs to be a pilot or co-pilot with a regional airline. Hoyt (1967) stated, "For utility and safety, whether the aircraft are today's or tomorrow's, a pilot must be competent [emphasis added]" (p. 30). Twenty years later, at a conference held at the University of North 
Dakota, Hughes (1987) related the following comments by Brady, President of Express Air 1:

The quality of replacement pilot candidates for the regionals is down dramatically, according to Brady. His company recently installed a basic instrument simulator to check the skills of applicants. In several cases, this screening weeded out candidates who had several thousand hours in their logbooks, but could not perform such basic instrument procedures as a holding pattern entry. (p. 96)

Why then are entry-level pilot skills not as good as they were five years ago? Moll (1990) stated it this way, "Rapid promotion erodes the seasoning process, making solid pilot training at the outset more important than ever" ( $p$. 34).

\section{Procedures for Data Collection and Analyses}

\section{Design of the study}

This study used "The Single Cross Section" sample surveyresearch design suggested by Warwick \& Lininger (1975, p. 57). Campbell and Katona (1966) previously had stated, "This is the method 'par excellence' for the determination of the characteristics of a population at a specific point in time" (p. 22). And, the general objective of this study was to determine if there is a need for additional training of entrylevel pilots, and if so, what additional training is needed.

The dependent variable was "need for additional training of entry-level pilot." It is a dependent qualitative variable with 5 levels. These levels were rated on an ordinal scale from 1 to 6 by the respondents. The independent variable was "regional airline," an assigned rather than manipulated variable.

\section{The Sample}

The sample size used in this study was 126 United States Regional Airlines, and was the correct size, according to the sample size formula shown by the Research Division of the National Educational Association (National Education Association [NEA], 1960, December, p. 99). Summary data of the population, random sample, usable and unusable surveys returned, and non-respondents of this study are shown in Table 1 . 
Table 1. Summary data of the population, random sample, usable surveys returned by regional airlines, unusable surveys returned, and non-respondents of this study.

\begin{tabular}{lllll}
\hline \multirow{3}{*}{$\begin{array}{l}\text { Population } \\
\text { Random }\end{array}$} & $\begin{array}{l}\text { Regional } \\
\text { Usable }\end{array}$ & $\begin{array}{l}\text { Anlines } \\
\text { Snuble } \\
\text { Surveys }\end{array}$ & $\begin{array}{l}\text { Non- } \\
\text { Respondents }\end{array}$ \\
\hline \multirow{2}{*}{186} & 126 & $\begin{array}{l}102 \\
(80.9)\end{array}$ & $\begin{array}{l}10 \\
(7.9)\end{array}$ & $\begin{array}{l}14 \\
(11.1)\end{array}$ \\
\hline
\end{tabular}

${ }^{a}$ Numbers shown in ( ) are percentages based on the random sample. Because of rounding, these percentages only total 99.9 .

\section{Type of Statistical Analyses Chosen}

Data obtained from the questionnaires used in this nonexperimental survey-research study are appropriate for descriptive studies. In processing the data gathered, the researcher used The student edition of minitab (Schaefer \& Anderson, 1989), a statistical software package.

Kruskal-Wallis $\mathrm{H}$ Test. This test (one-way analysis of variance for ranked data) is a rank test for $k$ independent samples, and the most appropriate test for significance of any ranking differences in the data collected from the survey questionnaires. The Kruskal-Wallis $H$ test was chosen because the data gathered were ordinal in nature, but not ordered.

The respondents rated each flight-training area with respect to need for additional training of entry-level pilots. The respondents used the following scale: (a) 1-No Importance, (b) 2-Little Importance, (c) 3-Some Importance, (d) 4Important, (e) 5-Highly Important, and (f) 6-Extremely Important.

Table 2 shows the data collected from the survey questionnaires by regional airlines. There were no missing data. 
Table 2. Sum of rating, mean rating, and rank of areas of flight training with respect to need for additional training of entry-level airline pilots (regional airlines).

\begin{tabular}{lccc}
\hline & $\underline{N}=102$ & & \\
Area of Flight Training & $\begin{array}{c}\text { Sum of } \\
\text { Rating }\end{array}$ & $\begin{array}{c}\text { Mean } \\
\text { Rating }\end{array}$ & Rank \\
\hline $\begin{array}{l}\text { Basic instrument training } \\
\text { (flight or simulator) }\end{array}$ & 512 & 5.02 & 1 \\
$\begin{array}{l}\text { Cockpit or crew resource } \\
\text { management training }\end{array}$ & 371 & 3.64 & 3 \\
$\begin{array}{l}\text { Phase I or phase II } \\
\text { simulator training }\end{array}$ & 255 & 2.50 & 5 \\
$\begin{array}{l}\text { Turbo-prop/jet in-flight } \\
\text { training } \\
\begin{array}{l}\text { Line-oriented flight } \\
\text { training }\end{array}\end{array}$ & 289 & 2.83 & 4 \\
\hline
\end{tabular}

Analyses: Need for Additional Training

Null hypothesis. There are no differences between types of entry-level pilot training, with respect to need for additional training of entry-level pilots, perceived as most important by chief pilots of regional airlines.

Testing the null hypothesis. Table 3 shows the summary of the data gathered from the survey questionnaires, after it was ranked, for the purpose of testing the null hypothesis. The Kruskal-Wallis $\mathrm{H}$ test adjusted for ties was used on this data. The .05 level of significance was selected in the analysis.

The data consist of 510 ratings, 102 per area of additional flight training. These data were ranked and all ties were assigned the average of the ranks they would otherwise occupy. It was assumed, in testing the null hypothesis, that the rank sums would be equal for the five areas of training and no significant differences would be found among types of additional entry-level pilot training. 
Table 3. Median, sum of rank, average rank, and $\underline{Z}$ value with respect to need for additional training of entrylevel pilots (regional airlines $\underline{\mathrm{N}}=102$ ).

\begin{tabular}{lcccc}
\hline Additional Training Area & Median & $\begin{array}{l}\text { Sum Rank } \\
\text { of Rank }\end{array}$ & $\begin{array}{c}\text { Ave. } \\
\text { Value }\end{array}$ \\
\hline $\begin{array}{l}\text { Basic instrument training } \\
\text { (flight or simulator) }\end{array}$ & 380.5 & 38764 & 380.0 & 9.54 \\
$\begin{array}{l}\text { Cockpit or crew resource } \\
\text { management training }\end{array}$ & 289.0 & 26379 & 258.6 & 0.24 \\
$\begin{array}{l}\text { Phase I or phase II } \\
\text { simulator training }\end{array}$ & 189.5 & 16710 & 163.8 & -7.02 \\
$\begin{array}{l}\text { Turbo-prop/jet in-flight } \\
\text { training }\end{array}$ & 189.5 & 19584 & 192.0 & -4.87 \\
$\begin{array}{l}\text { Line-oriented flight } \\
\text { training }\end{array}$ & 289.0 & 28868 & 283.0 & 2.11 \\
\hline
\end{tabular}

andicates how the average rank for that group differs from the average rank for all groups. The average rank for all groups $=255.6$.

The calculated $\mathrm{H}$ corrected for ties was 138.8. The distribution of $\mathrm{H}$ approximates the distribution of $\chi^{2}$ with ( $\mathrm{k}$ - 1) $\mathrm{df}$. For $\underline{\mathrm{k}}=5, \underline{\mathrm{df}}=4, \mathrm{a} \chi^{2}=9.49$ is required for significance at .05 level. Since 138.8 is $>9.49$, for $\underline{\text { df }}=4$, $\mathrm{p}<.05$, the null hypothesis was rejected.

Ten Wilcoxon rank sum tests were used as Post-Hoc tests for comparing all possible pairs of flight training areas. One seeks the normal deviate $\underline{Z}$ when using these tests. The results of these Wilcoxon tests are shown in Table 4 .

The null hypothesis under test here, in using the wilcoxon rank sum test, is that the medians of the paired flight training areas are equal. A $\underline{Z}$ value of \pm 1.96 is required for significance at the .05 level.

"Basic instrument training (flight or simulator)" was compared to (a) "cockpit or crew resource management training," (b) "phase I or phase II simulator training," (c) "turbo-prop/jet in-flight training," and (d) "line-oriented flight training." The respective $\underline{Z}$ values obtained were $6.37,9.91,8.75$, and $5.09, \mathrm{p}<.05$ for each pairing. The null hypothesis was rejected in each of these cases. 
The degree of association between the areas of need for additional training of entry-level pilots, is reflected in the variation in the rank sums. The null hypothesis under test here is that no association exists between the training areas, with respect to need for additional flight training. To test the null hypothesis the mean rho was found by the doing a Spearman rank-order correlation coefficient test on the 10 possible pairs of data, see Table 5. The rho mean value was then tested for significance by using a $\underline{t}$.

Findings: Need for Additional Training

The null hypothesis was rejected as a result of the KruskalWallis $H$ test. This result indicated that at least one pair of types of entry-level pilot training, with respect to need for additional training, was not from the same population. As a result of the Post-Hoc tests, the null hypothesis was rejected for all but two possible pairs of types of pilot training, with respect to need for additional

Table 4. Calculated $\underline{z}$ values for training area (TA) matrix with respect to need for additional training of entry-level pilots (regional airlines $\mathrm{N}=102$ ).

\begin{tabular}{|c|c|c|c|c|}
\hline & $\mathrm{TA}-2$ & $\mathrm{TA}-3$ & $\mathrm{TA}-4$ & $T A-5^{e}$ \\
\hline $\begin{array}{l}T A-1^{a} \\
T A-2^{b} \\
T A-3^{c} \\
T A-4^{d}\end{array}$ & $6.37^{\star}$ & $\begin{array}{l}9.91^{*} \\
4.94^{*}\end{array}$ & $\begin{array}{l}8.75^{\star} \\
3.44^{*} \\
1.38\end{array}$ & $\begin{array}{r}5.09^{\star} \\
1.25 \\
5.95^{\star} \\
12.34^{\star}\end{array}$ \\
\hline
\end{tabular}

${ }^{\mathrm{a}} \mathrm{TA}-1$ = Basic instrument training (flight or simulator).

${ }_{\mathrm{TA}-2}=$ Cockpit or crew resource management training.

${ }^{c} \mathrm{TA}-3=$ Phase I or phase II simulator training.

${ }_{\mathrm{TA}-4}=$ Turbo-prop/jet in-flight training.

TA-5 = Line-oriented flight training.

$\mathrm{p}<.05$

Table 5. Calculated $\rho$ values for training area (TA) matrix with respect to need for additional training of entry-level pilots (regional airlines $\underline{\mathbf{N}}=102$ ).

\begin{tabular}{|c|c|c|c|c|}
\hline & $\mathrm{TA}-2$ & $T A-3$ & $\mathrm{TA}-4$ & $T A-5^{e}$ \\
\hline $\begin{array}{l}T A-1^{a} \\
T A-2^{b} \\
T A-3^{c} \\
T A-4^{d}\end{array}$ & 0.107 & $\begin{array}{l}0.155 \\
0.381\end{array}$ & $\begin{array}{l}0.142 \\
0.388 \\
0.482\end{array}$ & $\begin{array}{r}0.049 \\
0.197 \\
-0.062 \\
0.100\end{array}$ \\
\hline
\end{tabular}


Note. Tho mean $=0.194$

${ }^{a} \mathrm{TA}-1$ = Basic instrument training (flight or simulator).

${ }^{\mathrm{T}} \mathrm{TA}-2=$ Cockpit or crew resource management training.

TA-3 = Phase I or phase II simulator training.

$\mathrm{TA}-4=$ Turbo-prop/jet in-flight training.

$\mathrm{e}_{\mathrm{TA}-5}=$ Line-oriented flight training.

training, as perceived by chief pilots of regional airlines. The result of the spearman rank-order correlation coefficient test shows that the null hypothesis could not be rejected. Therefore, the obvious associations between the two pairs of areas of need for additional training of entry-level pilots, as previously noted, were insignificant when tested with the other flight training areas.

\section{Discussion and Recommendations}

On the basis of this study's findings the following discussion and recommendations are made:

Many proficient entry-level pilots with only a few hundred flight-hours, who are pursuing an airline career, lose their instrument skills by the time they meet the total time/hours requirement of regional airlines. As pointed out in the study, the additional flight training needed is basic instrument flight training. Apparently these entry-level pilots lose their instrument proficiency (instrument skills) because they neglect basic instrument flying in order to accumulate the required flight time needed to be hired by regional airlines. Therefore, it is recommended that:

1. Colleges and universities with professional pilot training programs should investigate the feasibility of flying internships, for commercial and instrument certificated flight students, with air-taxi/charter companies. Flight internships should be considered even if a second pilot is not required under certification of the aircraft, or the regulations under which the flight is conducted.

2. The FAA should be petitioned to establish an addendum to Part 61.51, Pilot logbooks. The addendum should address internship flight-students from FAA approved flight schools, whereby they may log the experience or training while occupying a command seat of an air-taxi/charter flight, even if a second pilot is not required under certification of the aircraft, or FARs the flight is conducted under. 


\section{LIST OF REFERENCES}

Campbell, A. A. \& Katona, G. (1966). The sample survey: A technique for social-science research. In L. Festinger \& D. Katz (Eds.), Research methods in the behavioral sciences (pp. 15-55). New York: Holt, Rinehart and Winston.

Hoyt, K. K. (1967, July). Flight business will boom . . . part 2: A boom spirit will speed progress. Airport Services Management, $\underline{7}(7)$, pp. 34-35.

Hughes, D. (1987, October 5). Four-year pilot hiring boom creates problems for carriers. Aviation Week \& Space Technology, 127(14), pp. 95-97.

Jeppesen. (1981, April 24). Regulations. (Jeppesen airway manual services). Englewood, CO: Jeppesen Sanderson, Inc.

McArtor challenges top pilots to reduce flight crew errors. (1987, August 31). Aviation Week \& Space Technology, $\underline{127}(9)$, p. 34 .

Moll, N. (1990, April). Comair aviation academy: Aiming for the airliner cockpit. Flying, $117(4)$, pp. 34,37 .

National education association research bulletin. (1960, December). Small-sample techniques (p. 99). Washington, $\overline{\mathrm{DC}}$ : Research Division of the National Education Association.

Ott, J. (1990, June 25). Solving pilot attrition, training problems seen as key to easing safety concerns. Aviation Week \& Space Technology, 132(26), pp. 41-42.

Proctor, P. (1988, December 12). Study urges upgrade in commuter training. Aviation Week \& Space Technology, $129(24)$, p. 126 .

Regional Airline Association. (1990, Annual). 1990 annual report of the regional airline association. Washington, DC: Author.

Schaefer, R. L., \& Anderson, R. B. (1989). The student edition of minitab. Reading, Massachusetts: AddisonWesley.

Schukert, M. A., \& Maples, W. R. (1990, October 9). Corporate pilot hire education. Business aviation issues (Edition 90-4). Washington, DC: National Business Aircraft Association. 
Simulators, revised FAA standards will enhance regionals' crew training. (1988, June 13) A Aviation Week \& Space Technology, $128(24)$, pp. 127,129 .

Warwick, D. P., \& Lininger, C. A. (1975) . The sample survey: Theory and practice. New York: McGraw-Hill. 